\title{
Prospects of iontophoresis in cardiovascular drug delivery
}

\begin{abstract}
Clinical benefits, industry interest, regulatory precedence, and strong market potential have made transdermal research the fastest growth area in drug delivery. As most drugs permeate poorly through skin, a major challenge is achieving the therapeutic level by enhancement of permeation rate. Iontophoresis, utilizing a minimal amount of current, is found to affect the skin permeation process drastically. Ideally suited for protein drugs, attempts have been made to utilize the technology for accelerating the low-molecular-weight drugs for chronic administration. However, because of the difficulty associated with the energy supply, commercialization was not feasible until recent times. Fortunately, the unprecedented growth of microelectronics has bridged this lacuna and brought the technology right into limelight. This article analyses the advantages of electrically assisted drug delivery in relation to passive permeation, with special reference to some cardiovascular drugs, for which there is already a demand in the market.
\end{abstract}

Key words:

Cardiovascular, flux, iontophoresis, passive permeation, transdermal

\section{Introduction}

Worldwide, the pharmaceutical industry is facing multiple challenges. The ever-changing safety regulations related to the drug use demands the development of dosage forms, which would be able to deliver drugs at specific sites, preferably through non-invasive routes in a ratecontrolled manner. The biotechnologically produced protein drugs also need parallel delivery devices because of their inherent instability in gastrointestinal tract. Presently, the pharmaceutical research is focused on the development of improved delivery routes for the existing drugs. In this context, dermal delivery has generated a lot of interest. In the last decade, $40 \%$ of the drug delivery candidates under clinical evaluation in United States belonged to the transdermal category. ${ }^{[1]}$ However, the route was thought to be of questionable worth for the hydrophilic drugs, as they resulted in inadequate skin permeation..$^{[2]}$ Stratum corneum, the outermost skin layer, a thin matrix of dehydrated dead keratinocytes $(10-15 \mu \mathrm{m})$, is designed by nature to minimize the trans-epidermal water loss. Only small molecules, neutral and lipophilic, can pass through them in limited quantity. ${ }^{[3]}$ The permeants experience high resistive force while traversing the complicated lipophilic-hydrophilic serial pathways of the

\begin{tabular}{|l|c|}
\hline \multicolumn{2}{|c|}{ Access this article online } \\
\hline \multirow{2}{*}{$\begin{array}{l}\text { Website: } \\
\text { www.jbclinpharm.org }\end{array}$} & Quick Response Code \\
\hline & \\
DOI: & \\
10.4103/0976-0105.109407 & \\
& \\
\hline
\end{tabular}

skin. For most of the molecules, the skin resistance is too high to be overcome by the concentration gradient, which is the driving force of passive permeation. Enhancer molecules can increase the permeation rate, but are prone to cause irreversible skin damage and irritation. ${ }^{[4]}$ Physical propulsion of the drug molecules into the deeper layers of the skin was thought to be a safer alternative.

The first reports of iontophoresis had appeared in the turn of the century when Leduc demonstrated the technique by delivering strychnine and cyanide into rabbits in $1908 .^{[5]}$ But reports of burns and skin damages associated with the use of electric current created dubious repercussions about the utility of the process for routine administration of drugs. ${ }^{[6,7]}$ The interest was revived only after some 60 years by the pioneering work of a group of researchers who had shown that drug permeation could be safe and successfully enhanced by using low-intensity controlled current, bringing the electrically assisted drug delivery back into the

Bijaya Ghosh, Dhanalakshmi lyer', Anroop B. Nair ${ }^{2}$, Harsha N. Sree ${ }^{2}$

Department of Pharmaceutics, NSHM College of Pharmaceutical Technology, NSHM Knowledge Campus, Kolkata, West Bengal, 'K.L.E.S's College of Pharmacy, Bangalore, Karnataka, India, ${ }^{2}$ Pharmaceutical Sciences, College of Clinical Pharmacy, King Faisal University, Al-Ahsa, Kigdom of Saudi Arabia

Address for correspondence: Dr. Bijaya Ghosh, Department of Pharmaceutics, NSHM College of Pharmaceutical Technology, NSHM Knowledge Campus, Kolkata, West Bengal - 700 053, India. E-mail: bijayadd@yahoo.co.in 
limelight. ${ }^{[8]}$ Against intravenous infusions, current-induced controlled delivery is projected to have higher patient compliance, as it is associated with minimum of histological damage and spares the recipient of psychological trauma of needle. ${ }^{[9]}$

Last two decades have seen biotechnologically produced proteins, added to the repertoire of drugs, which due to their macromolecular nature are unstable and unable to pass the gastro-intestinal barrier. ${ }^{[10]}$ But, the problem looked less complicated when it was discovered that they could slip through the aqua-filled pores when repelled by an electric force. ${ }^{[11]}$ Data obtained from the studies of smaller molecules also projected iontophoresis, an electrically driven delivery device, as a promising tool for routine non-invasive drug administration. Lidocaine has already reached the US market as an iontophoretic patch. ${ }^{[12]}$ Needing an additional energy source, the iontophoretic devices are bound to be expensive compared to the passive patches. Hence, to be commercially viable, iontophoretic delivery must have certain advantages over their passive counter parts. Analysis is normally done on this aspect before selecting a candidate for the iontophoretic system development.

The pharmaceutical journals are an abundant reservoir of both simple and iontophoretic studies. But, fewer attempts have been undertaken to compare and evaluate the data obtained from the processes. In this review, we attempt to examine and analyze the prospects of iontophoretic research as well as potential benefits of the technique above and over that of passive permeation, with special reference to cardiovascular drugs.

\section{Basic features of iontophoresis}

An iontophoretic device needs an energy source in addition to the conventional drug reservoir. The source once activated generates the energy in programmed and controlled manner. Since the patches are to be worn on the body, the battery that provides current should be small, convenient to wear, and inexpensive, making the challenge formidable for the system developers. Fortunately, giant leaps in microelectronics have bridged that gap and made the theoretical approach a practicability. The technique works by principle of electrostatic repulsion of charges; hence, to be of use, the drug must be in the ionic form. Electric current creates a potential gradient across the skin tissue and from the drug reservoir placed below the active electrode, charged drug gets repelled. Positive ions were delivered by anode and negative ions by cathode [Figure 1]. The process is particularly beneficial for the drugs which produce positively charged ions. Skin has a net negative charge at physiological $\mathrm{pH}$ and cations cross the skin barrier better than the anions. For anions belonging to the molecular range of 35 - 500 Dalton, iontophoretic flux decreases with increasing molecular size. ${ }^{[13]}$ Since the permeability of stratum corneum in the presence of electric current is altered, uncharged water-soluble molecules can also permeate the skin by electro-osmosis. ${ }^{[14]}$ As carriers of electricity, hydrophilic drug that ionizes at physiological $\mathrm{pH}$ gets priority. These drugs permeate through the water-filled natural pores of the skin that takes them to the root of the pores, from where systemic uptake is very rapid. Since the

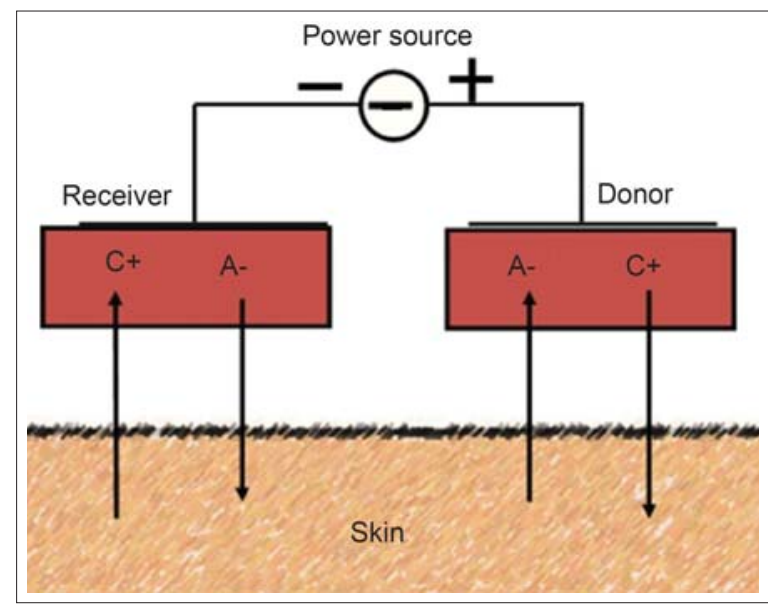

Figure 1: Schematic representation of a typical transdermal iontophoretic system showing the electromigration transport of charged cationic drug molecules $\left(\mathrm{C}^{+}\right)$into skin

pore diameter of human skin (22-54 $\AA$ ) are much wider and linear than the tortuous irregular path that run through the lipophilic matrix of the unbroken skin, the permeation is speedy and enhanced. ${ }^{[15]}$ As the iontophoretic propulsion is directly proportional to the intensity of the current, the technique is likely to ensure the programmed and reproducible delivery of drug substances, to fulfill the demand of modern therapy.

Commercially available passive patches carry small molecules and have evaded the interest of the iontophoretic researchers so far. The above molecules by virtue of their low molecular weight and good lipophilicity can permeate through the lipophilic skin matrix at an adequate rate without the assistance of active energy supply. The follicular area of the skin is only $0.1 \%$, and small molecules can utilize both unbroken skin as well as the shunt pathway of the follicular route. ${ }^{[16]}$ Here, the use of electricity can result in no or minimal benefit. In iontophoresis, the follicular route because of its aqueous environment is predominantly utilized, though there is a nominal contribution from the passive flux too. Hence, the high-molecular-weight drug that cannot accommodate into the narrow slits of the unbroken skin gets a decided advantage in the iontophoretic process. In electrically repelled drug delivery, the total permeation is the sum of iontophoresis, electro-osmosis, and passive flux; the electrostatic repulsion being the predominant one. ${ }^{[1]}$ Moreover, for the biotechnologically produced peptide drugs, iontophoresis seems to be the ideal route for non-invasive, rate controlled, and reproducible drug delivery.

\section{Approaches of iontophoretic research}

Iontophoretic system development is a multidisciplinary research activity and can be broadly classified into several areas. While the energy supply device is a specialized microelectronic research zone, formulation development needs to address certain key issues; the pathways of percutaneous penetration be characterized, rate limiting steps in transdermal absorption be identified; the specific drug structure-penetration relation be understood; and the 
safety factors of the process on skin be evaluated. ${ }^{[18]}$ Laser scanning confocal microscopy and vibrating probe electronic technique are being utilized to ascertain the penetration mechanism of molecules. ${ }^{[19]}$ Investigations on pindolol had indicated that radial mass transport is the dominant mechanism of iontophoresis. ${ }^{[15]}$ Identifying the preference of skin for specific ions and structures can also optimize a formulation. ${ }^{[20]}$ Measurement of skin impedance and reversibility are usually carried out to evaluate the safety factors, optimizing drug delivery. ${ }^{[21]}$ However, the key factor on which the pharmaceutical research is focused on is the enhancement of permeation, which can result in beneficial therapeutic efficacy of drugs. ${ }^{[22]}$ Being a promising approach, researchers are assessing the feasibility of this technique to extract the drug molecule from the subdermal region for a noninvasive therapeutic drug monitoring. ${ }^{[23]}$

\section{Iontophoresis and cardiovascular drugs}

A recent market survey by Cleary and Beskar had shown that in terms of sales, the analgesic patch, fentanyl has reached the status of a blockbuster product with an annual turn over of 1.59 billion US dollars in the year 2002. ${ }^{[12]}$ However, the patches belonging to the cardiovascular category were rated to be of higher clinical benefit. The major reasons could be the requirement of steady-state concentration throughout the treatment and ensure safe therapy. ${ }^{[24,25]}$ The only commercially available antihypertensive patch of clonidine and two antianginal patches of nitroglycerine and isosorbide dinitrate have made significant contribution in therapy in terms of reduction of cardiovascular emergencies. American heart association has endorsed the utility of transdermal nitroglycerine in acute myocardial infarction, irrespective of involvement of left ventricular failure. ${ }^{[26]}$ A retrospective analysis of the Medicaid claims in two American states had shown that though the prescription expenditure of the patients using the clonidine patch was significantly higher, it saved them from hospitalization and reduced the overall health expenditure. ${ }^{[27]}$ Indeed, development of the transdermal cardiovascular agents became a prime research objective. Drugs belonging to these groups are getting extensively investigated for transdermal development and both passive and energy-assisted permeation are being attempted. Table 1 compares the flux values of both the processes and the benefits associated with use of electrical energy.

The ultimate challenge in passive delivery is the reproducibility of drug flux. Usually, experiments are designed to achieve a target flux, calculated from the reported pharmacokinetic data using in vivo animal models. Flux values obtained from passive permeation are subjected to variations by species, skin type, and skin area. Similarly, electrical impedance of skin also varies widely amongst the species, individuals, as well as the location of the body parts. Studies carried out in animal species again vary significantly from that of human beings. Iontophoresis uses trans-follicular pathway and the follicle densities of animals and humans were different. Tailormade artificial skin offering resistance comparable to that of human skin is the ideal choice for the comparative study. For in vivo studies, the comparison becomes more complicated because of the different volume of distributions. Exactly matching experiments were rare and permeation efficiencies of passive and active processes were compared in Table 1, by using data obtained from grossly similar experiments. Flux values obtained depend upon the concentration as well as the characteristics of the donor vehicles. Increase in drug supply in donor usually results in higher flux value in passive permeation, whereas iontophoretic flux is proportional to the energy supply as long as a sufficient donor concentration is maintained. Since the donor concentrations used by different researchers were different, the quantitative comparison of flux values becomes meaningless and flux enhancement becomes a more appropriate parameter.

In Table 2, the comparisons of the flux enhancement with that of physicochemical parameters reveal some puzzling pattern. Metoprolol tartrate, the drug with highest water solubility, showed a moderate benefit of 1.8 times enhancement in iontophoresis as compared to the passive flux. This may result from its high partition coefficient that makes it accommodative into the lipophilic stratum corneum that constitutes $99.9 \%$ of the skin surface. In such cases, the contribution of the passive process in the total iontophoretic flux turns significant and the net benefit of electrical energy is moderate. ${ }^{[28]}$

In case of propranolol hydrochloride and nadolol, the drugs were delivered from special vehicles containing ionexchange resins. ${ }^{[29]}$ For propranolol hydrochloride, two passive permeation data vary widely indicating the effect of species variation. As usual, higher flux was reported through the mice skin, ${ }^{[30]}$ whereas in human the passive permeation was very low compared to the iontophoretic flux. Since the drug has moderate water solubility and freebase shows high lipophilicity, enhancement effect of iontophoresis can be attributed to the assistance of the ion-exchange resins. For nadolol, the free base is much less lipophilic than propranolol and the contribution of passive permeation is likely to be less. So, iontophoresis showed a drastic enhancement. ${ }^{[29]}$ Timolol maleate has somewhat similar parameters to that of propranolol hydrochloride, but the benefits of iontophoresis were somewhat lower. ${ }^{[31,32]}$ However, the donor used in this experiment is plain water and there was no assistance of the ion-exchange resins.

Being low-molecular-weight and water-soluble drug, atenolol qualifies as a good candidate for iontophoresis theoretically. ${ }_{[30,31]}$ However, the iontophoretic permeation conducted by Dennet et al. showed widely variable pattern. In twenty-hour long current application, the initial permeation rate was low, and then the rate increased drastically. ${ }^{[31]}$ Though a discount can be given for species variation, the average iontophoretic flux was 30\% lower compared to that of a passive experiment. ${ }^{[30]}$ The results indicate that theoretically ideal candidates may not always be a best bet for iontophoretic system development. The only in vivo comparison cited in the table is for the drug captopril. It shows much higher benefit in iontophoresis than that of passive permeation. ${ }^{[34]}$ Since the drug gets extensively ionized at the physiological $\mathrm{pH}$ and has a low octanolwater partition coefficient, the results match the theoretical expectation. ${ }^{[33]}$

\section{Common approaches to enhance the iontophoretic flux}

Optimization of the iontophoretic delivery needs 


\begin{tabular}{|c|c|c|c|c|c|c|}
\hline \multirow[t]{2}{*}{ Drugs } & \multicolumn{3}{|c|}{ Passive permeation } & \multicolumn{3}{|c|}{ Iontophoresis } \\
\hline & $\begin{array}{l}\text { Study type } \\
\text { (Skin used) }\end{array}$ & $\begin{array}{c}\text { Donor solution/ } \\
\text { system }\end{array}$ & $\begin{array}{l}\text { Flux/plasma } \\
\text { concentration }\end{array}$ & $\begin{array}{l}\text { Study type } \\
\text { (Skin used) }\end{array}$ & $\begin{array}{c}\text { Donor solution/ } \\
\text { system }\end{array}$ & $\begin{array}{c}\text { Flux/plasma } \\
\text { concentration }\end{array}$ \\
\hline $\begin{array}{l}\text { Metoprolol } \\
\text { Tartarate }^{[28]}\end{array}$ & $\begin{array}{c}\text { In vivo } \\
\text { (microporous } \\
\text { membrane) }\end{array}$ & $\begin{array}{c}1.7 \mathrm{mmol} / \mathrm{g} \\
\text { loaded in ion- } \\
\text { exchange fiber }\end{array}$ & $\begin{array}{c}54.3 \pm 4.10 \\
\left(\mu \mathrm{g} / \mathrm{cm}^{2} / \mathrm{h}\right)\end{array}$ & $\begin{array}{c}\text { In vivo } \\
\text { (microporous membrane- } \\
\text { using } 0.1 \mathrm{~mA} / \mathrm{cm}^{2} \text { ) }\end{array}$ & $\begin{array}{l}\text { Loaded in ion- } \\
\text { exchange fiber } 1.7 \\
\text { mmol/g }\end{array}$ & $\begin{array}{c}97.6 \pm 5.10 \\
\left(\mu \mathrm{g} / \mathrm{cm}^{2} / \mathrm{h}\right)\end{array}$ \\
\hline \multirow[t]{2}{*}{$\begin{array}{l}\text { Propranolol } \\
\text { Hydrochloride }\end{array}$} & $\begin{array}{l}\text { In vivo } \\
\text { (Human) }\end{array}$ & $\begin{array}{l}50 \mathrm{mg} / \mathrm{ml} \\
\text { solution in cation- } \\
\text { anion exchange } \\
\text { fibers }\end{array}$ & $\begin{array}{c}0.26 \pm 0.07 \\
\left(\mu \mathrm{g} / \mathrm{cm}^{2} / \mathrm{h}\right)\end{array}$ & $\begin{array}{c}\text { In vivo } \\
\text { (Human-0.5mA/ } \mathrm{cm}^{2} \text { ) }\end{array}$ & $\begin{array}{l}50 \mathrm{mg} / \mathrm{ml} \text { solution } \\
\text { in cation-anion } \\
\text { exchange fibers }\end{array}$ & $\begin{array}{l}43 \pm 7.00 \\
\left(\mu \mathrm{g} / \mathrm{cm}^{2} / \mathrm{h}\right)\end{array}$ \\
\hline & $\begin{array}{l}\text { In vivo } \\
\text { (Mice) }\end{array}$ & $\begin{array}{c}16.27 \mathrm{mg} / \mathrm{ml} \\
\text { aqueous solution }\end{array}$ & $\begin{array}{c}107.71 \\
\left(\mu \mathrm{g} / \mathrm{cm}^{2} / \mathrm{h}\right)\end{array}$ & & & \\
\hline Nadolol|29] & $\begin{array}{l}\text { In vivo } \\
\text { (Human) }\end{array}$ & $\begin{array}{l}5 \%(\mathrm{~m} / \mathrm{v}=50 \\
\mathrm{mg} / \mathrm{ml}) \text { solution } \\
\text { in cation-anion } \\
\text { exchange fibers }\end{array}$ & $\begin{array}{c}0.04 \pm 0.05 \\
\left(\mu \mathrm{g} / \mathrm{cm}^{2} / \mathrm{h}\right)\end{array}$ & $\begin{array}{c}\text { In vivo } \\
\text { (Human-0.5mA/ } \mathrm{cm}^{2} \text { ) }\end{array}$ & $\begin{array}{c}5 \%(\mathrm{~m} / \mathrm{v}=50 \\
\mathrm{mg} / \mathrm{ml}) \text { solution } \\
\text { in cation-anion } \\
\text { exchange fibers }\end{array}$ & $\begin{array}{l}49 \pm 7.00 \\
\left(\mu \mathrm{g} / \mathrm{cm}^{2} / \mathrm{h}\right)\end{array}$ \\
\hline \multirow[t]{2}{*}{$\begin{array}{l}\text { Timolol } \\
\text { maleate } \mathrm{e}^{[1,32]}\end{array}$} & $\begin{array}{l}\text { In vivo } \\
\text { (Human-stratum } \\
\text { corneum) }\end{array}$ & $\begin{array}{l}40 \mathrm{mg} / \mathrm{ml} \\
\text { solution }\end{array}$ & $\begin{array}{c}3 \pm 2 \\
\left(\mu \mathrm{g} / \mathrm{cm}^{2} / \mathrm{h}\right)\end{array}$ & $\begin{array}{c}\text { In vivo } \\
\text { (Human stratum } \\
\text { corneum }-0.5 \mathrm{~mA} / \mathrm{cm}^{2} \text { ) }\end{array}$ & $40 \mathrm{mg} / \mathrm{ml}$ solution & $\begin{array}{l}240 \pm 49 \\
\left(\mu \mathrm{g} / \mathrm{cm}^{2} / \mathrm{h}\right)\end{array}$ \\
\hline & $\begin{array}{l}\text { In vivo } \\
\text { (Rodents) }\end{array}$ & Non specified & $5\left(\mu \mathrm{g} / \mathrm{cm}^{2} / \mathrm{h}\right)$ & & & \\
\hline Captopril|[33] & $\begin{array}{l}\text { In vivo and In vivo } \\
\text { (Rat) }\end{array}$ & Hydrogel & $\begin{array}{l}\text { No captopril } \\
\text { detected }\end{array}$ & $\begin{array}{l}\text { In vivo and In vivo } \\
\text { (Rat) }\end{array}$ & Hydrogel & $\begin{array}{l}0.9 \mu \mathrm{g} / \mathrm{ml} \text { in } \\
\text { plasma after } 1 \mathrm{~h}\end{array}$ \\
\hline Atenolo| $\left.\right|^{[30,31]}$ & $\begin{array}{l}\text { In vivo } \\
\text { (Mice) }\end{array}$ & $\begin{array}{l}22.90 \mathrm{mg} / \mathrm{ml} \\
\text { in methanolic } \\
\text { solution }\end{array}$ & $\begin{array}{c}76.57 \\
\left(\mu \mathrm{g} / \mathrm{cm}^{2} / \mathrm{h}\right)\end{array}$ & $\begin{array}{c}\text { In vivo } \\
\text { (Human stratum } \\
\text { corneum }-0.25 \mathrm{~mA} / \mathrm{cm}^{2} \text { ) }\end{array}$ & $40 \mathrm{mg} / \mathrm{ml}$ & $\begin{array}{c}54.45 \\
\left(\mu \mathrm{g} / \mathrm{cm}^{2} / \mathrm{h}\right)\end{array}$ \\
\hline
\end{tabular}

\begin{tabular}{|c|c|c|c|c|}
\hline Drug & Molecular weight & $\begin{array}{l}\text { Solubility } \\
\text { (Temp) }\end{array}$ & $\log P^{*}$ & Effect of iontophoresis on drug flux \\
\hline Propranolol hydrochloride & 295.8 & $\begin{array}{c}104.2 \mathrm{mg} / \mathrm{ml} \\
\left(37^{\circ} \mathrm{C}\right)^{[34]}\end{array}$ & 3.56 & Significant enhancement (170 folds) in in vivo permeation \\
\hline Captopril & 217.3 & $\begin{array}{c}>100 \mathrm{mg} / \mathrm{ml} \\
\left(25^{\circ} \mathrm{C}\right)\end{array}$ & $1.02 * * *$ & $\begin{array}{l}\text { Detectable plasma level of the drug by iontophoresis in } \\
\text { contrast to no permeation in passive diffusion }\end{array}$ \\
\hline Timolol maleate & 432.5 & $\begin{array}{c}>33.3 \mathrm{mg} / \mathrm{ml} \\
\left(25^{\circ} \mathrm{C}\right)\end{array}$ & 1.91 & 80 folds enhancement in permeation \\
\hline Metoprolol tartrate & 684.8 & $\begin{array}{c}>1000 \mathrm{mg} / \mathrm{ml} \\
\left(25^{\circ} \mathrm{C}\right)\end{array}$ & 1.88 & A moderate enhancement of 1.8 folds \\
\hline Atenolol & 266.3 & $\begin{array}{c}31.2 \mathrm{mg} / \mathrm{ml} \\
\left(37^{\circ} \mathrm{C}\right)^{[34]}\end{array}$ & 0.16 & Widely fluctuating permeation profile \\
\hline Nadolol & 309.4 & $\begin{array}{c}46 \mathrm{mg} / \mathrm{ml} \\
\left(37^{\circ} \mathrm{C}\right)\end{array}$ & 0.71 & A drastic 1225 times rise in the permeation rate was noted. \\
\hline
\end{tabular}

standardization of various parameters, the condition of the skin, the formulation excipients, but the most important and investigated area is the mode and duration of energy supply. Mode of energy supply influences the flux and hence investigation is carried out for the desired current density as well as the pattern of energy supply. Switching iontophoresis, i.e., switching of the polarity of electrodes on transdermal absorption was one of the approaches adopted. It was seen that verapamil permeation was greater at certain switching interval and permeability coefficient and cumulative amount both improved significantly. ${ }^{[35]}$ Increasing the current density usually increases mass transport, but a limiting value of $0.5 \mathrm{~mA} / \mathrm{cm}^{[2]}$ is thought to be safe and satisfactory in most of the cases. ${ }^{[36]}$

For the formulation parameters, optimization is usually done with ionic strength, $\mathrm{pH}$, buffer types, special adjuvants, and the membranes incorporated in the formulation. In case of captopril, iontophoretic flux was significantly affected by factors like $\mathrm{pH}$, ionic strength, drug concentration, etc. ${ }^{[33]}$ Use 
of special adjuvants like ion exchange resins in the device is also found to be beneficial. ${ }^{[26]}$ In certain cases, transdermal permeation shows stereo-selectivity. Certain researchers have tried to optimize the permeation by investigating this approach. ${ }^{[37]}$ Manipulation of the association state and formation of the charged analogues may turn out to be a useful approach to enhance the iontophoretic delivery. Formation of the insulin analogues with extra negative charges had shown beneficial results in terms of 50 to 100 times flux enhancement. ${ }^{[20]}$

Skin hydration was found to be an important parameter that can enhance the permeation rate. Similarly, extracting the skin lipids by treatment with alcohol can facilitate the delivery. So, efforts are also on to optimize the permeation rate by this basal treatment. ${ }^{[20]}$ Use of permeation enhancers in the donor vehicle to enhance the iontophoretic flux is another approach investigated by some researchers. ${ }^{[38]}$ As electroporation and iontophoresis both have same common denominator of electro-repulsion, attempt is also being taken to enhance iontophoretic flux by decreasing the skin impedance by an initial electroporation. ${ }^{[31]}$

\section{Conclusion}

Drug delivery is not the only area where iontophoresis is thought to be of practical use. It has already found use in the diagnostic area. Reverse iontophoresis is used in the noninvasive monitoring of the glucose level for diabetics. ${ }^{[39]}$ It is getting investigated for the development of a diagnostic test for the determination of phenylketonuria, a potentially fatal metabolic disease in infants. ${ }^{[40]}$ The technique is also useful for assessing vascular functions. ${ }^{[41]}$ Though the opponents of iontophoresis argue that electroporation can be a better substitute for active drug delivery rather than iontophoresis, the technique fares better in terms of both safety and efficacy. It also shows more promise than the micro-conduit technology, which uses the targeted impact of high-energy micro-particles on specified areas on skin surface to create pores for non-invasive sampling of analyte as well as drug administration. ${ }^{[42]}$ The electroporation technique requiring much higher voltage, i.e., 100-1000V, can give rise to hazardous side effects and is likely to be a component of specialized healthcare zone, while the hi-tech micro-conduits technology is still in its infancy. On the other hand, iontophoretic systems involving low level of electricity can be constructed with a 9-volt button cell and can be easily commercialized. Cardiovascular agents because of their demand for chronic administration have already had an assured market for transdermal products. The advanced state of research in this field indicates that iontophoretic administration of such drugs is likely to be a reality in the near future.

\section{References}

1. Cross SE, Roberts MS. Physical enhancement of transdermal drug application: Is delivery technology keeping up with pharmaceutical development? Curr Drug Deliv 2004;1:81-92.

2. Flynn GL. Physicochemical determinants of skin absorption. In: Gerrity TR, Henry CJ, editors. Principles of route to route extrapolation for risk assessment. New York: Elsevier; 1990. p. 98-127.

3. Bos JD, Meinardi MM. The 500 Dalton rule for the skin penetration of chemical compounds and drugs. Exp Dermatol 2000;9:165-9.

4. Smith EW, Maibach HS, editors. Percutaneous penetration enhancers. Boca Raton: CRC Press; 1995.

5. Leduc S, editor. Electric ions and their use in medicine. London: Rebman Ltd; 1908.

6. Singh J, Gross M, Sage B, Davis HT, Maibach HI. Regional variations in skin barrier function and cutaneous irritation due to iontophoresis in human subjects. Food Chem Toxicol 2001;39:1079-86.

7. Meyer BR, Kreis W, Eschbach J, O'mara V, Rosen S, Sibalis D. Transdermal versus subcutaneous leuprolide: A comparison of acute pharmacodynamic effect. Clin Pharmacol Ther 1990;48:340-5.

8. Banga AK, editor. Electrically assisted transdermal and topical drug delivery. London: Taylor and Francis Ltd; 1998.

9. Merino V, Kalia YN, Guy RH. Transdermal therapy and diagnosis by iontophoresis. Trends Biotechnol 1997;15:288-90.

10. Pillai O, Borkute SD, Sivaprasad N, Panchagnula R. Transdermal iontophoresis of insulin II. Physicochemical considerations. Int J Pharm 2003;254:271-80.

11. Panchagnula R, Pillai O, Nair VB, Ramarao P. Transdermal iontophoresis revisited. Curr Opin Chem Biol 2000;4:468-73.

12. Cleary GW, Beskar E. Transdermal and transdermal like delivery system opportunities. Drug Deliv Technol 2003;3:35-40.

13. Roberts MS, Lai PM, Cross SE, Yoshida NH. Solute structure as a determinant of iontophoretic transports. In: Potts RO, Guy RH, editors. Mechanisms of transdermal drug delivery. New York: Marcel Dekker; 1997. p. 291-349.

14. Barry BW. Novel mechanisms and devices to enable successful transdermal drug delivery. Eur J Pharm Sci 2001;14:101-4.

15. Ferry LL. Theoretical model of iontophoresis utilized in transdermal drug delivery. Pharma Acta Helv 1995;70:279-87.

16. Chien YW. Transdermal drug delivery and delivery systems. In: Swarbrick J, editor. Novel drug delivery system, New York: Marcel Dekker; 1992. p. 301-80.

17. Shanti P, Catellani PL, Massimo G, Zanardi G, Colombo P. Iontophoretic transport of verapamil and melatonin I. Cellophane membrane as a barrier. Int J Pharm 1993;92:23-8.

18. Guy R. Iontophoresis-recent developments. Pharm Pharmacol 1998;50:371-4.

19. Kirjavainen M, Urtti A, Monkkonen J, Hirvonen J. Influence of lipids on the mannitol flux during transdermal iontophoresis in vivo. Eur J Pharm Sci 2000;10:97-102.

20. Langkjaer L, Brange J, Grodsky GM, Guy RH. Iontophoresis of monomeric insulin analogues in vivo: Effects of insulin charge and skin pretreatment. J Control Release 1998;51:47-56.

21. Kobayashi I, Hosaka K, Ueno T, Maruo H, Kamiyama M, Konno C, et al. Relationship between the amount of propranolol permeating through stratum corneum of guinea pig skin after application of propranolol adhesive patches and skin irritation. Biol Pharm Bull 1996;19:839-44.

22. Peck KD, Srinivasan V, Li SK, Higuchi WI, Ghanem AH. Quantitative description of the effect of molecular size upon electroosmotic flux enhancement during iontophoresis for a synthetic membrane and human epidermal membrane. J Pharm Sci 1996;85:781-8.

23. Nair AB, Goel A, Prakash S, Kumar A, Therapeutic drug monitoring by reverse iontophoresis. J Basic Clin Pharm 2012;3:207-13.

24. Nair AB, Vyas H, Kumar A. Controlled release matrix uncoated tablets of enalapril maleate using HPMC alone. J Basic Clin Pharm 2010;1:71-4.

25. Ogochukwu AM, Victoria UC. A review of anti-hypertension therapies in diabetic patients. J Basic Clin Pharm 2010;1:139-45.

26. Taylor SH. The role of nitroglyerine in the treatment of coronary heart disease. Amer Heart J 1986;112:197-207.

27. Grafe F, Wohlrab W, Neubert R, Brandsch M. Carrier mediated transport of clonidine in human keratinocytes. Eur J Pharm Sci 2004;21:309-12.

28. Vuorio M, Murtomaki L, Hirvonen J, Kontturi K. Ion exchange fibers and drugs: A novel device for the screening of iontophoretic systems. J Control Release 2004;97:485-92. 
29. Jaskari T, Vuorio M, Kontturi K, Urtti A, Manzanares A, Hirvonen J. Controlled transdermal iontophoresis by ion-exchange fiber. J Control Release 2000;67:179-90.

30. Anroop B, Ghosh B, Parcha V, Kumar A, Khanam J. Synthesis and comparative skin permeability of atenolol and propranolol esters. J Drug Del Sci Tech 2005;15:187-90.

31. Dennet A, Ucakar B, Preta V. Transdermal delivery of timolol and atenolol using electroporation and iontophoresis in combination: A mechanistic approach. Pharm Res 2003;20:1946-51.

32. Dennet A, Preat V. Transdermal delivery of timolol by electroporation through human skin. J Control Release 2003;88:253-62.

33. Ghosh B, Reddy LH. Effect of physicochemical parameters on skin permeability of antihypertensive. Indian J Exp Biol 2001;39:710-4.

34. Wang H, Hou HM. Improvement of transdermal permeation of captopril by iontophoresis. Acta Pharmacol Sin 2000;21:591-5.

35. Ishikawa O, Kato Y, Onishi H, Nagai T, Machida Y. Enhancement of transdermal absorption by switching iontophoresis. Int J Pharm 2002;249:81-8

36. Stamatialis DF, Rolevink HH, Gironès M, Nymeijer DC, Koops GH. In vivo evaluation of a hydroxypropyl cellulose gel system for transdermal delivery of timolol. Curr Drug Deliv 2004;1:313-9.

37. Conjeevaram R, Chaturvedula A, Betageri GV, Sunkara G, Banga AK. Iontophoretic in vivo transdermal delivery of beta-blockers in hairless rats and reduced skin irritation by liposomal formulation. Pharm Res 2003;20:1496-501.

38. Babu RJ, Pandit JK. Effect of penetration enhancers on the release and skin permeation of bupranolol from reservoir-type transdermal delivery system. Int J Pharm 2005;288:325-34.

39. Leboulanger B, Guy RH, Delgado-Charro MB. Reverse iontophoresis for non-invasive transdermal monitoring. Physiol Meas 2004;25:R35-50.

40. Merino V, Lopez A, Hochstrasser D, Guy RH. Non-invasive sampling of phenylalanine by reverse iontophoresis. J Control Release 1999;61: 65-9.

41. Ramsay J, Ferrell W, Greer I, Sattar N. Factors critical to iontophoretic assessment of vascular reactivity: Implications for clinical studies of endothelial dysfunction. J Cardiovasc Pharmacol 2012;39:9-17.

42. Herndon TO, Gonzalez S, Gowrishankar TR, Anderson RR, Weaver JC. Transdermal microconduits by microscisson for drug delivery and sample acquisition. BMC Med 2004;2:12.

How to cite this article: Ghosh B, lyer D, Nair AB, Sree HN. Prospects of iontophoresis in cardiovascular drug delivery. J Basic Clin Pharma 2013;4: 25-30.

Source of Support: Nil, Conflict of Interest: No. 